\title{
Industry 4.0 - Challenge to Human Resources
}

\author{
Toni Mihova \\ Technical University of Sofia, branch of Plovdiv \\ Plovdiv, Bulgaria \\ mihova@tu-plovdiv.bg
}

\author{
Ivelina Ivanova \\ Technical University of Sofia, branch of Plovdiv \\ Plovdiv, Bulgaria \\ iva_1982@abv.bg
}

\begin{abstract}
The report examines the key role of human resources in implementing the digital transformation of business processes in Bulgarian industrial enterprises. The survey was conducted in fifty-eight industrial enterprises in Bulgaria; the participants in the study were $232 \mathrm{HR}$ managers and specialists. The main method of research is the questionnaire and the paper contains the results of the analysis of this questionnaire.
\end{abstract}

Keywords - adaptability, competencies, digitalization, expertise.

\section{INTRODUCTION}

We are witnessing the new megatrend in the development of the industry after the globalization in the 80s, namely - its digitalization. The convergence of the real and virtual worlds is becoming more tangible and leads to Industry 4.0. The review of research and analysis to determine the main prerequisites for the rapid digitalization of the industry indicates technological changes in several interrelated areas - large databases, cloud technologies and platforms for sharing digital skills, mobile communications, social technologies and their applications [1], [2], [3], [4]. This, in turn, is a prerequisite for the key role of human resources in the implementation of processes related to the digital transformation of industrial enterprises.

The aim of the study is to determine whether the human resources (HR) in industrial enterprises meet the new requirements for the implementation of radical changes and what needs to be done regarding the skills, competencies, expertise and adaptability in the conditions of Industry 4.0.

To achieve this goal we make a literature review of the issues, describe the methodology of the study, indicate the results and on this basis formulate conclusions about the challenges facing human resources and their management in the conditions of Industry 4.0.

\section{LITERARY REVIEW}

\section{A. Basic views of Fourth Industrial Revolution}

One of the most popular definitions of the nature of the fourth industrial revolution is that of Klaus Schwab, who characterized it as building on the foundations of the digital revolution and combining many technologies that led to unprecedented changes in the economy, society and the individual [5]. In The Fourth Industrial Revolution, Schwab describes the main features of the new technological revolution and outlines the opportunities and dilemmas it brings. The important contribution of the author is that he sees this revolution as our own creation and points out the ways in which we can steer it in a certain direction so that it can be used for the benefit of all. According to Klaus Schwab, the fourth industrial revolution is based on the merging of technologies, which blurs the boundaries between the physical, biological and digital spheres. Other authors, based on Schwab's concept, characterize the digital economy by emphasizingits benefits for Bulgaria and the European Union.

They also look at the obstacles that hinder the development of the digital economy, as well as the measures that have been taken to overcome them [6]. An in-depth study and analysis of the nature and distinctive features of Industry 4.0 was made in the book "The Fourth Industrial Revolution - Nature and Problems" (Damyanov, D., 2019). It examines the possibilities for bringing conventional technologies to Industry 4.0 , as well as develops practical implementations of implementation models for Industry 4.0 [7]. In the Concept for digital transformation of the Bulgarian industry, the considered concept Industry 4.0 is defined as part of the application of new digital technologies in the manufacturing sector and includes a wide range of technological solutions and business models that contribute to qualitatively new forms of economic activity [8]. The term Industry 4.0 was first 
defined by the German Federal Government as the main initiative for the adoption of a high-tech strategy for the development of German industry in 2011 (part of the HighTech Strategy 2020 for Germany). years, the term appears in specific strategies (for example - the Trade and Investment Agency in Germany). The term "Industry 4.0" is used in the name of 8 of the 13 national policies in the EU for digitization of production processes (Fig.1).

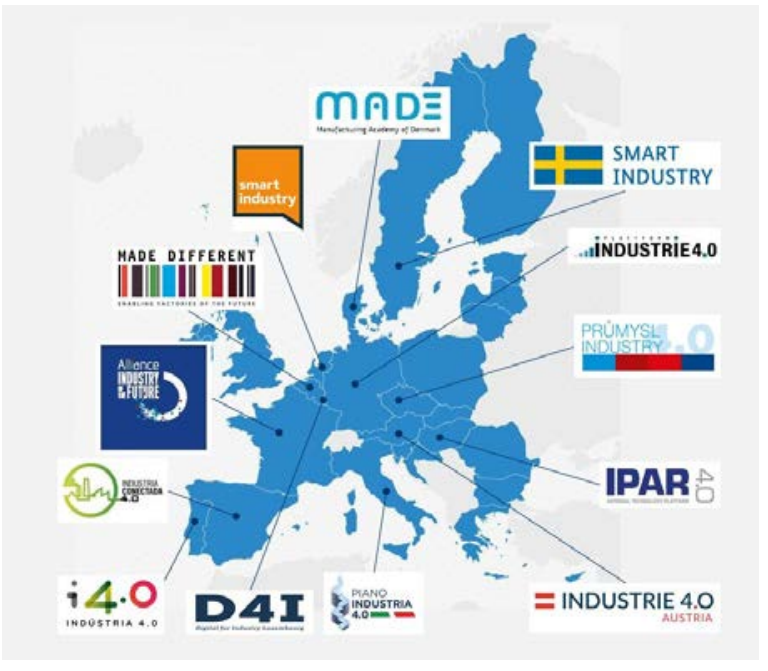

Fig. 1. Use of the term,Industry 4.0” in the national policies of EU countries

The article "Digital Transformation of Bulgarian Enterprises in the Conditions of Industry 4.0” is of high practical applicability, in which the authors give guidelines for creating an adequate digital infrastructure to support the transformation of Bulgarian industrial enterprises [9]. The aspect that is of interest for our research is related to the challenges to human resources in the conditions of Industry 4.0.

B. Basic views of the challenges to human resources in the conditions of Industry 4.0.

Industrial enterprises face opportunities forradical changes in business models and the overall organization of activities. The review of the specialized literature shows us a number of modern researches on the considered problems [10]. Most companies with a long history and experience are mobilizing to adapt to these changes: many seek to reach the next horizon of operational achievements through the direct use of emerging technologies, while others try to develop new business models (new production organizational models). factories, developing new virtual markets). Combined, these efforts will almost inevitably lead to a complete transformation of the entire organization in the industry [11]. Undoubtedly, all these changes are made by human resources. This implies anticipation and training of professionals with skills according to evolving technologies, which will have a direct impact on business and society, as well as on individuals [12]. In the article "Industry 4.0 - will machines displace people?" the key role of people in the process of digital transformation of enterprises is precisely and clearly substantiated. The main arguments are related to the fact that human resources will create processes and innovations, they will implement and regulate them [13]. The article lists the 5 most important skills for Industry 4.0, summarized by Network World, as follows:

- Cybersecurity. Cyber security will be a major concern for companies. The reason is that many internet-based devices will be implemented in the production process, which will connect to existing machines. As the chain grows and connects to the World Wide Web, the risk of cyberattacks increases, including the extent of possible damage.

- Data specialists. Digital data is the lifeblood of Industry 4.0, which makes the people who work with it extremely valuable. The development of IoT will generate a huge amount of data that will need to be stored and analyzed. The aim is to be able to use them to improve the productivity of machines, reduce resource consumption, support quality control, improve the efficiency of supply chains and introduce new products and services.

- Networking. Here comes the skills of highly qualified network engineers to connect machines to each other and to management and control systems. They will have toassess the challenges posed by connecting systems and machines that have never been designed for networking. A significant factor in this process will be the cloud system.

- Software engineers, developers and programmers. The spectrum here is huge, as these jobs will be needed in different forms throughout the range of the industrial ecosystem. People will be needed to write and modify machine programs, as well as develop new interfaces. Companies will also need professionals who know how to encode high-level languages such as Java, but also older ones such as $\mathrm{C}$ and $\mathrm{C}++$. They will face the challenge of connecting existing systems and machines to new generations of platforms

- Architects. IT architects will play a role in assisting systems engineers in the process of unifying the physical and logical worlds. These people will have to understand in depth the dimensions of the existing business, its processes and goals in the direction of its digital transformation. And then they have to figure out how to tie it all together with technology. In short, these are the most important skills, competencies and expertise needed in the digital age to enable industrial enterprises to transform their business models and overall organization. The digitalization of Human Resource's activities has also been studied by the world-famous specialist in the field of HR theories and practice Prof. Dave Ulrich. He substantiates his claim that HR practices respond to changing external conditions (eg social, technological or political trends) and external stakeholders. Shifting the logic of HR to the outside requires $\mathrm{HR}$ professionals to truly understand the organization's business so that they can make the connection between their own work and the added value for stakeholders. The main conclusion he draws is that digitalization in HR work will not replace the human judgment and insight regarding the talent, leadership and organization needed to succeed in the marketplace [14]. The literature review on this issue allows us to find a 
Environment. Technology. Resources. Rezekne, Latvia Proceedings of the $13^{\text {th }}$ International Scientific and Practical Conference. Volume 2, 112-115

number of researchers on the role of Human Resource management (HRM) in the digital environment, the change of HRM activities to be sustainable companies in the digital age, the requirements for individual and organizational competencies in the new environment and cooperation mechanisms. "Human beings" and "smart things" [15].

\section{MATERIALS AND METHODS}

The survey was conducted in fifty-eight industrial enterprises in Bulgaria in the period June 2020 - January 2021. Twenty-nine of them are enterprises with foreign management (Germany, France, Austria, Sweden, Denmark, Italy, Belgium, etc.), and the rest are Bulgarian industrial enterprises. Industrial enterprises are large and medium-sized enterprises in the South Central region of the sectors: „Manufacture of food products", „Manufacture of clothing", „Manufacture of beverages", „Manufacture of tobacco products", „Manufacture of paper, paperboard and paper products" and cardboard”, „Printing and reproduction of recorded media”, „Manufacture of chemical products”, „Manufacture o Industry $4.0 \mathrm{f}$ machinery and equipment ”, „Manufacture of electrical equipment ”, „Repair and installation of machinery and equipment“, „Manufacture of computer and communication equipment, electronic and optical products”, „Leather processing; manufacture of footwear and other leather products”. The surveyed enterprises employ 34,627 people. The participants in the study were $232 \mathrm{HR}$ managers and specialists, with $4 \mathrm{HR}$ specialists from each company participating. 142 are women and $93-$ men. All of them are high educated ; 8 are with Ph,D. degree. Of these, 116 work in enterprises with foreign management. We conditionally designate these participants in the study with Group A. The other 116 respondents are HR managers and specialists in Bulgarian industrial enterprises. These are the participants from Group B. The study covers four stages: development of surveys; conducting the survey; processing of the results; determining the percentage of responses.

TABLE 1 RESULTS OF THE STUDY

\begin{tabular}{|c|l|l|l|}
\hline № & \multicolumn{1}{|c|}{ Question } & Group A & Group B \\
\hline 1. & $\begin{array}{l}\text { How do you assess the } \\
\text { digital competencies of } \\
\text { your employees? }\end{array}$ & & \\
& - high level; \\
& - average; \\
& - satisfactory; & $12 \%$ & $6 \%$ \\
- low level. & $51 \%$ & $25 \%$ \\
\hline 2. & $\begin{array}{l}\text { To what extent do you } \\
\text { manage to recruit and } \\
\text { select employees with } \\
\text { the required digital } \\
\text { competencies and } \\
\text { expertise? }\end{array}$ & & $42 \%$ \\
& - to a high degree; & & \\
- on average; & $8 \%$ & \\
\hline
\end{tabular}

\begin{tabular}{|c|c|c|c|}
\hline & $\begin{array}{l}\text { - to a low degree; } \\
\text { - we fail. }\end{array}$ & $\begin{array}{r}39 \% \\
6 \%\end{array}$ & $\begin{array}{l}49 \% \\
14 \%\end{array}$ \\
\hline 3. & $\begin{array}{l}\text { Has a strategy been } \\
\text { developed for } \\
\text { digitalization of HR } \\
\text { activities in the } \\
\text { enterprise? } \\
\text { - Yes; } \\
\text { - under construction; } \\
\text { - no. }\end{array}$ & $\begin{array}{l}5 \% \\
48 \% \\
47 \% \\
\end{array}$ & $\begin{array}{l}2 \% \\
26 \% \\
72 \% \\
\end{array}$ \\
\hline 4. & $\begin{array}{l}\text { What digital approaches } \\
\text { and tools do HR } \\
\text { professionals use to } \\
\text { recruit and select HR? } \\
\text { - Social networks } \\
\text { (Linkedin, Twitter, } \\
\text { Facebook); } \\
\text { - Applicant tracking } \\
\text { systems; } \\
\text { - Artificial Intelligence; } \\
\text { - video interviews; } \\
\text { - mobile selection tools. }\end{array}$ & $\begin{array}{l}82 \% \\
25 \% \\
26 \% \\
45 \% \\
68 \% \\
\end{array}$ & $\begin{array}{l}65 \% \\
\\
12 \% \\
15 \% \\
26 \% \\
45 \% \\
\end{array}$ \\
\hline 5. & $\begin{array}{l}\text { What digital approaches } \\
\text { and tools do HR } \\
\text { professionals use to } \\
\text { train HR? } \\
\text {-interactive video } \\
\text { training; } \\
\text {-adaptive and } \\
\text { personalized training; } \\
\text {-microlearning (through } \\
\text { short videos); } \\
\text {-chat bot; } \\
\text { - gamification. }\end{array}$ & $\begin{array}{l}87 \% \\
42 \% \\
23 \% \\
32 \% \\
53 \%\end{array}$ & $\begin{array}{l}74 \% \\
25 \% \\
10 \% \\
16 \% \\
24 \%\end{array}$ \\
\hline
\end{tabular}

The questionnaire contain 5 questions related to the needs for recruitment and selection of human resources with digital competencies and expertise; with the degree of success to select such specialists; with the development of a strategy for digitalization of HR activities and the use of digital tools in the processes of recruitment, selection and training of human resources (Table 1).

\section{RESULTS AND DISCUSSION}

Conducting the third stage of the study - "Processing of results", allows us to make the following summaries: 1 . In the enterprises with foreign management, $51 \%$ of the employees have an average level of digital competencies, while in the Bulgarian industrial enterprises, this percentage is significantly lower - $25 \%$. 2. The selection of the employees with the required digital competencies and expertise is carried out successfully to a high degree by $47 \%$ of the surveyed enterprises from Group A, and in Group B - by $32 \%$ of the respondents. 3 . The majority of 
the surveyed enterprises from the first group - 53\% have or are in the process of developing a strategy for digitalization of HR activities, while in the Bulgarian industrial enterprises, $72 \%$ do not have such a strategy. 4. Significantly more of the enterprises with foreign management, in comparison with the Bulgarian enterprises, use digital tools and approaches in recruitment and selection of HR - social networks (Linkedin, Twitter, Facebook); Applicant Tracking Systems (ATS); Artficial Intelligence (AI); video interviews mobile selection tools. 5. Significantly more of the enterprises with foreign management, in comparison with the Bulgarian enterprises use digital tools and approaches for training of HR interactive video training; adaptive and personalized training; micro-learning (via short videos); chat bot; gamification. The results of the study were discussed with the representatives of the companies participating in the study by holding a remote round table. The main issues discussed, after acquainting the participants with the specific results, are related to the difficulties and problems in the digital transformation of HR activities.

\section{V.CONCLUSIONS}

Industry 4.0 poses a number of challenges to human resources - they need to have new competencies and expertise, as a result of which to adapt to the digital environment. In this regard, changes in human resource management are needed. The results of the study show that at this stage, Bulgarian industrial enterprises still, for the most part, do not have a strategy for digitalization of HR and a small percentage of them use the necessary digital approaches and tools for recruitment and selection, training and development of human resources. . In this regard, we can systematize the main guidelines for changing $\mathrm{HR}$ activities to respond to the changing external environment as follows:increasing the digital competencies and expertise of HR specialists;

- creating an atmosphere for improving the attitudes of employees towards digitalization of $\mathrm{HR}$ activities in industrial enterprises;

- use of the necessary digital approaches and tools in the implementation of recruitment and selection, training and development and motivation of HR.

In the report we tried to point out the new challenges that Industry 4.0 poses to human resources, as well as on the basis of our own research to reveal the current state of competencies and expertise of human resources. The problems that stand out as a result of the analysis of the information from the research are the basis for the formulation of guidelines for overcoming them. Through the effective management of human resources will be able to recruit and select, as well as prepare in companies the right employees - with the necessary digital competencies and expertise, which will lead to successful digital transformation of business models and the overall organization of industrial enterprises.

\section{ACKNOWLEDGMENTS}

The author/s would like to thank the Research and Development Sector at the Technical University of Sofia for the financial support.

\section{REFERENCES}

[1] D. Chaffey, Digital Business and E-commerce Management, $6^{\text {th }}$ Edition, Pearson UK home, 2015

[2] G. C. Kane, D. Palmer, A. N. Phillips, D. Kiron and N. Buckley. Strategy, Not Technology, Drives Digital, 2015

[3] D.Chaffey, Managing Digital Transformation Guide, 2014 [Online] Available: http://www.smartinsights.com/guides/managingdigitaltransformation-guide/

[4] The Digital Transformation of Business (2015) HBR Report, [Online] Available: https://hbr.org/resources/pdfs/comm/microsoft/the digital transfor mation_of business.pdf

[5] K. Shwab, The Fourth Industrial Revolution, Penguin Books Ltd, London, United Kingdom, 2017

[6] G. Nikolov, L. Tsenova, L. Chetvartata industrialna revolyutsiya i digitalnata ikonomika, https://www.researchgate.net/

[7] D. Damyanov, T. Geshev and K. Chukalov, Chetvarta industrialna revolyutsiya - sashtnost i problemi, , IK „KING”, ISBN:978-9549518-97-9, 2019

[8] Kontseptsiya za tsifrova transformatsiya na balgarskata industriya (industriya 4.0), www.mi.government.bg

[9] T.Gigova, K.Valeva, V. Nikolova-Alexieva, Digital Transformation -Opportunity for Industrial Growth, 2019 International Conference on Creative Business for Smart and Sustainable Growth (CREBUS), Sandanski, Bulgaria, 18-21 March 2019, INSPEC Accession Number: 18994787, DOI: 10.1109/CREBUS.2019.8840102

[10] D. Shatarova, E. Zlatanova-Pazheva, , Human resources in the digital age - trends and challenges,Scientific researches of the Union of Scientists in Bulgaria - Plovdiv, series B.Natural Sciences and the Humanities, Vol. XVIII, ISSN-1311-9192 (Print), ISSN-2534-9376 (On-line), 2018

[11] M. Russman , M. Lorenz , Ph. Gerbert , M. Waldner , J. Justus,, P. Engle and M. Harnisch, Industry 4.0: The future of productivity and growth in manufacturing industries, The Boston Consulting Group, 2015

[12] T. A.Leopold , V. Ratcheva and S. Zahidi.: The Future of Jobs Employment, Skills and Workforce Strategy for the Fourth Industrial Revolution, World Economic Forum, Davos, 2016

[13] M. Velikov, „Industriya 4.0 - shte izmestyat li mashinite horata?”, sp.’Tvoyat biznes”, br.95, 2017

[14] D. Ulrih:Digitalizatsiyata na HR rabotata nyama da zamesti choveshkata pretsenka, https://www.capital.bg/

[15] D. El-Khoury, "Digital transformation and the world-class HR difference", Strategic HR Review, Vol. 16 No. 2, pp. 86-88. https://doi.org/10.1108/SHR-01-2017-0001, (2017) 